\title{
B-Cell Activating Factor Measurement
}

National Cancer Institute

\section{Source}

National Cancer Institute. B-Cell Activating Factor Measurement. NCI Thesaurus. Code C111135.

The determination of the amount of B-cell activating factor present in a sample. 